\title{
Parrhesia and the ethics of public service - towards a genealogy of the bureaucrat as frank counsellor
}

\author{
EDWARD BARRATT \\ University of Essex, United Kingdom
}

\begin{abstract}
Foucault makes clear in his later lectures that the notion of parrhesia has a long and varied history, which he merely sketches in his investigations of ancient politics and philosophy. Recent research extends and modifies Foucault's genealogy of parrhesia as an aspect of the practice of the adviser or counsellor of a monarch or prince, showing how parrhesia informed notions of counsel at other times: in later antiquity, the middle ages as well as early modern Europe. Here we seek to show that the ancient notion of parrhesia reappears as a graft in another domain of modern truth telling: that of bureaucracy in Britain, in the debates over the organisation of the offices of government, with the middle years of the nineteenth century a decisive moment of rupture. We consider the fate of bureaucratic frank counsel in our own era. Interpreters of Foucault's later lectures on governmentality have analysed the consequences of neoliberal rule for the government of public servants during the era of Margaret Thatcher. Presenting a reappraisal of the era, we show how important counter-discourses also emerged in this era, bringing the ethics of office to the fore, as civil servants argued for the formal codification of bureaucratic ethics, including frank counsel, as they tried to defend their professional ethics. Our discussion therefore addresses a key, early moment in the emergence of the ideal of codifying frank counsel and bureaucratic ethics. We consider the consequences of codification, arguing that a deep ambivalence now characterises the way in which political authorities seek to govern this domain of ethical practice.
\end{abstract}

Keywords: parrhesia, bureaucracy, civil service, ethics, codification.

\section{INTRODUCTION}

Defined broadly as a form of courageous and truthful frank speaking, performed out of duty to others in ancient politics and philosophy, Foucault ${ }^{1}$ presents his analysis of parrhesia in the final lectures as a superficial account requiring extensive further research - work that he was unable to undertake. Parrhesia, he suggests, is a 'spidery'

\footnotetext{
${ }^{1}$ Michel Foucault, Fearless Speech (2001), 11-20; Michel Foucault, The Hermeneutics of the Subject [2001] (2005), 137; Michel Foucault, The Government of Self and Others [2008] (2010), 45-57; Michel Foucault, The Courage of Truth [2008] (2011), 1-19.
} 
and elusive notion with an extended history, manifest in varied historical settings, moving from one doctrine or system to another. ${ }^{2}$ Initially an essential element of political discourse in Athenian democracy, with Socrates, parrhesia became an aspect of the practice of ancient philosophy and, as such, an element of Cynic, Epicurean and Stoic philosophical practice. In the later lectures, Foucault also comments on the emergence of parrhesia as an aspect of the practice of counselling a monarch, as portrayed in the writings of Plato, Xenophon and Isocrates. ${ }^{3}$ He raises the possibility of a much longer history of parrhesia as a truth-telling activity that could be written, including an exploration of 'the dramatics' of the ministerial adviser to the monarch ${ }^{4} \mathrm{a}$ practice that accompanied the emergence of the discourse of reason of state as it took shape in sixteenth century Europe.

This discussion considers a related political modality of parrhesia - the 'dramatics' of frank counsel in a bureaucratic setting, that of the British Civil Service. As such, we respond to Colin Gordon's $\mathrm{s}^{5}$ argument that the later lectures enable, imply and demand a genealogy of forms of 'political culture, conduct, sociability and subjectivity' (see also Dean, 2016) to accompany the genealogy of the modes of governmentality that Foucault and his interpreters have attempted. We can, Gordon argues, seek to instrumentalise Foucault's work, using his thought for our own ends, ideally with as much freedom and inventiveness as we are capable of. But we can also seek to explore the many themes, suggested in the later writing, that Foucault was unable to develop. It is the latter possibility that we take up here.

Foucault reflected on disparate modern settings in which parrhesia reappeared, grafted onto other forms of truth-telling. The ancient notion of parrhesia informed the practice of an array of early modern critics of the authority of the Church and the emerging arts of state government. Critique in this form did not so much question government per se, but rather the excesses, limitations and perverse effects of particular practices of rule, affirming 'an art of not being governed or of not being governed like that and at this price'. ${ }^{6}$ Descartes and Kant, in so far as they sought to encourage a critical questioning of the existing order of state and church, were guided by this ancient ideal. ${ }^{7}$ Later, the nineteenth century revolutionaries - secret societies, anarchists, communists and trade unionists - owed much to the ancient Cynic practice of parrhesia $^{8}$ in fashioning politics as a militant mode of being, making the truth visible through a whole way of life. Cynic parrhesia also manifested itself in the 'militant' mode of life of the modern artist. Indeed, in the modern world, Foucault suggests, it is

\footnotetext{
${ }^{2}$ Foucault, Government of Self and Others, 45.

${ }^{3}$ Ibid., 180-283.

${ }^{4}$ Ibid., 69.

${ }^{5}$ Colin Gordon, “Governmentality and the genealogy of politics," Education and Research 39:4 (2013), 1054.

${ }^{6}$ Michel Foucault, “What is critique?" [1978] in What is Enlightenment?, ed, J. Schmidt (1996), 384.

${ }^{7}$ Government of Self and Others, 349-350.

${ }^{8}$ Foucault, Courage of Truth, 185.
} 
especially in modern art that the most normatively disruptive forms of truth-telling with the courage to take the risk of offending - are concentrated.$^{9}$

Here we seek to show that the ancient notion of parrhesia reappears as a graft in another domain of modern truth-telling: that of bureaucracy in Britain ${ }^{10}$ in programmes for the organisation of the offices of government, with the middle years of the nineteenth century a decisive moment of rupture. At this point, the virtue of 'independence', implying frank straightforwardness - a further transcription of parrhesia - was first defined as an essential quality of the senior public servant in a particular liberal parliamentary political regime by an influential alliance of political actors. ${ }^{11}$ This regime came to be known as the 'Westminster' system of politics and public administration, after many of the former colonies of the British Empire took on the favoured administrative and constitutional practices and ideals of the British upon achieving self-government. ${ }^{12}$

We go on to reflect on the recent history of 'bureaucratic frank counsel' in the British context. Interpreters of Foucault's later lectures on neoliberalism analyse the way in which ethical attributes of enterprise and responsiveness have displaced the customary ethics of public service, with the ascendancy of neoliberal rule. ${ }^{13}$ Revisiting the era in which neoliberalism first took shape as a practical programme for the government of Civil Service bureaucrats, we seek to qualify this view. With Conservative politicians and their allies calling into question the efficiency, economy and responsiveness of the offices of government, we show how important counter-discourses also emerged that brought the ethics of office to the fore. We comment especially on the part played by individual bureaucrats in this struggle. Years would pass before a formal ethical code for the Civil Service would be endorsed by the leaderships of the major political parties. But by 2010, both the British Labour and Conservative parties had agreed on the need for a formal inscription of a set of core bureaucratic ethics - integrity, honesty, objectivity and impartiality - in a code to have legal backing. ${ }^{14} \mathrm{~A}$ new code would provide a benchmark for right conduct, protect civil servants from being forced to act in ways that violated standards and a right of appeal where matters of conscience were at stake to a newly constituted Civil Service Commission. Leading politicians not only celebrated the ideal of the senior public servant speaking 'truth to power' - they fortified their commitment by means of legal reform.

Our discussion therefore addresses a key, early moment in the emergence of the ideal of codifying frank counsel and bureaucratic ethics. At the same time, we suggest that the arguments of the Conservatives' critics of the 1980s manifest a deep ambivalence,

\footnotetext{
${ }^{9}$ Ibid., 189.

${ }^{10}$ Parliamentary Papers (PP) (1854), 3-23.

11 Ibid., 3.

12 Roderick Rhodes, John Wanna and Patrick Weller, Comparing Westminster (2009), 1-20.

${ }^{13}$ Andrew Barry, Thomas Osborne and Nikolas Rose, "Introduction," in Foucault and Political Reason, eds. Andrew Barry, Thomas Osborne and Nikolas Rose (1996), 1-19; Nikolas Rose, Powers of Freedom (1999), 150. ${ }^{14}$ Francis Maude, Speech at Civil Service World Conference, 2009a; Gordon Brown, "Constitutional reform statement" [2007], in The Change We Choose (2010), 162.
} 
anticipating a tendency in recent political discourse. The habit of endorsing core bureaucratic values - including that of frank counsel and an associated code of ethics whilst promoting and extending practices that undermine those same values, appears to have become commonplace in recent times. In this regard, our perspective overlaps with the theorists of the 'new public governance' who highlight a similar tendency as the management of the Civil Service becomes more strategic, partisan and driven from the centre of government. ${ }^{15}$ We begin, however, by reflecting on Foucault's analysis of parrhesia as an aspect of advice or counsel in a political context, commenting on recent historiography which develops his brief analysis of 'political parrhesia' in later antiquity and in an early modern setting.

\section{PARRHESIASTIC EPISODES - ON THE HISTORIOGRAPHY OF FRANK COUNSEL}

As Gordon confirms, elements of Foucault's lecture series in 1982/3 can be interpreted as a contribution to a genealogy of the practice of political counsel, ${ }^{16}$ suggesting a field of historical enquiry encompassing the practice of ministerial counsel to the monarch in the European tradition of reason of state. ${ }^{17}$ Foucault was himself a 'counsellor of princes' for a time: to influential socialist politicians and ministers of state in the years of the reemergence of Francois Mitterand's French Socialist party. The extended account of Plato's unsuccessful attempt to offer moral counsel to the tyrant Dionysius in Sicily in the Seventh Letter often seems to resonate with Foucault's own experiences. ${ }^{18}$ In attempting to counsel Dionysius, ${ }^{19}$ Plato primarily pursued a goal of nurturing selfformation, but in a timely way, responding to the kairos: the opportune moment presented by the investiture of a new monarch seemingly sympathetic to Plato's practice. Plato acted as an outsider at court, alert to the risks of engagement, in an always provisional endeavour. He was not attempting to provide detailed and practical, policy advice but to enable the new king to practice philosophy, punctuating this with moments of context specific advice to the monarch, adjusted to the conjuncture, but at the level of principles. Above all, Plato was willing to enact parrhesia and speak frankly to Dionysius, bearing the risks of seeking to enable philosophical practice at court.

For Foucault, Plato's account of his efforts in Sicily - in addition to his brief observations in the Laws on the role of counsellors at the court of Cyrus in Persia and in Persian society - mark a turning point in the history of the concept of parrhesia. ${ }^{20}$ As an aspect of ancient politics, parrhesia referred to the practice of speaking boldly and frankly and was associated with those citizens who aspired to play a leading role in the

\footnotetext{
${ }^{15}$ Peter Aucoin, “New political governance in Westminster systems," Governance 25:2 (2012), 179.

${ }^{16}$ Colin Gordon, "Governmentality and the genealogy of politics," Education and Research 39:4 (2013), 1049.

17 Government of Self and Others, 70-71.

${ }^{18}$ Gordon, 'Governmentality and the genealogy of politics', 1062.

${ }^{19}$ Government of Self and Others, 209-280.

20 Ibid., 201-202.
} 
political 'joust' in the polis. ${ }^{21}$ For the ancient Greeks, a willingness to take risks, by articulating beliefs that challenged accepted opinion about the common good or that might offend another party with whom one was in a subordinate relationship, served as an indicator of sincerity and truthfulness. Plato, however, believed that speakers in Athenian democracy commonly tried to accomplish their own ends by flattering the crowd and appealing to their desires. Through Socrates, parrhesia became a key element in the ethical self-formation of Athenian citizens - especially the young aspiring to govern the city - as he boldly exposed their false opinions and pretensions. With Plato's account in the Seventh Letter, a similar ethical form of parrhesia came to be associated with the political setting of the court and the practice of the philosopher seeking to advance the ethical self-formation of the monarch - or to enable the 'philosopher king'. Foucault suggests that Plato provided an example that inspired practices of philosophical counsel at court in the Hellenistic period and in later antiquity.

More recent research develops Foucault's analysis identifying an array of varied historical settings in which the notion of parrhesia reappeared, whilst suggesting a number of important modifications, notably giving attention to the relationship between parrhesia and rhetoric, especially in the later imperial era. ${ }^{22}$ Consonant with Foucault's analysis, Van Renswoude argues for an essential consistency in the way in which the practice of the philosopher, as a counsellor to a monarch, was represented from the Hellenistic period through to the Roman Republic and the early Empire. ${ }^{23}$ The counsellor was always defined by his self-control, independence and freedom of speech, acting on behalf of a city state and articulating the grievances of its people. A philosopher was expected to live a simple, solitary life but to intervene in public affairs as circumstance required. An important break took place over the second century, as philosophers gradually became advocates of the imperial government and absorbed into the administration of the Empire. ${ }^{24}$ The art of rhetoric became increasingly important to the practise of the philosopher at court, with handbooks of advice containing guidance on how best to avoid offending the powerful.

Brown ${ }^{25}$ argues that over the course of the fourth century, monks, hermits and bishops assumed the 'ambassadorial' role of the ancient court philosophers. More recent scholarship ${ }^{26}$ confirms the legacy of this period in the early middle ages: the ideal of the frank-counselling holy man was revived in the era of the Merovingian dynasty as an essential comportment of the bishops who aspired to counsel at court. Later, in the socalled Carolingian renaissance, the ancient ideal of parrhesia again reappears, guiding

\footnotetext{
${ }^{21}$ Ibid., 157.

22 Peter Brown, Power and Persuasion in Late Antiquity (1992), 8; Irene Van Renswoude, The Rhetoric of Free Speech in Late Antiquity and the Early Middle Ages (2019), 7-8; Claudia Rapp, Holy Bishops in Late Antiquity: The Nature of Christian Leadership in an Age of Transition (2013), 182; Joanne Paul, Counsel and Command in early Modern English Thought (2020), 12.

${ }^{23}$ Irene Van Renswoude, The Rhetoric of Free Speech in Late Antiquity and the Early Middle Ages (2019), 65.

24 Ibid., 125.

${ }^{25}$ Brown, Power and Persuasion in late Antiquity, 4.

${ }^{26}$ Van Renswoude, Rhetoric of Free Speech in Late Antiquity, 135.
} 
the practice of the lay advisers and bishops who advised the king, as counsel assumed an increasingly institutionalised form. ${ }^{27}$

Of particular interest here, given our focus on the British setting, recent historiography confirms a later reappearance of the ideal of parrhesia: in the thought of the humanist advisers of the monarchy. ${ }^{28}$ Beginning in medieval England, the practice of counsel possesses an extended history, reflected in a large 'mirror of princes' literature: a body of prescriptive writing affirming the essential contribution of prudent counsel to the exercise of monarchical power. ${ }^{29}$ But as Paul ${ }^{30}$ argues, with the Renaissance revival and the 'northern humanist' return to classical sources, ${ }^{31}$ counsel came to be seen as more than an extension of a reciprocal feudal relationship of a subject to a monarch. For Paul, a key contribution of this 'revival' was to extend the range of concepts by means of which the nature of counsel was debated and discussed. Prominent humanists imagined counsel as an essential comportment of the exemplary citizen leading the active political life not only in the republican regime they associated with Cicero but in the monarchical regimes in which they lived, with their inherent tendencies to corruption and tyranny. Whether, like Erasmus, 32 they imagined themselves as an educator of a Prince or, like Thomas Elyot, ${ }^{33}$ as a philosopher-courtier, counsel was an essential means of advancing Ciceronian virtues of moderation, justice, courage and practical wisdom. Departing from Foucault's account of Plato in the Seventh Letter, a counsellor was therefore a philosophical authority in humanist discourse, enabling a ruler to embody virtue in its highest and purest form and providing a check on capricious and arbitrary monarchical rule.

To speak as a counsellor was to speak in 'friendship' in a way the humanists associated with the practice of the advisers of kings in Hellenistic antiquity and Plutarch's ${ }^{34}$ account of the complexities of differentiating a flatterer from a true friend. The flatterer constantly sought to criticise irrelevant faults or to please and praise indiscriminately, in an insincere way, exploiting the tendency towards self-love in the powerful. For Plutarch and those who interpreted him, parrhesia was the pre-eminent virtue of the true friend as a counsellor to a ruler. ${ }^{35}$ The freedom of speech with which the friend reproved the counselled for real faults was a weapon in the war on untruth

\footnotetext{
27 Rhetoric of Free Speech in Late Antiquity, 192.

${ }^{28}$ Joanne Paul, "Serving the public by advising the ruler," in The European Public Servant, eds. Fritz Sagar and Patrick Overeem (2015), 45.

${ }^{29}$ Conel Condren, Argument and Authority in Early Modern England (2006), 20; John Goy, "The rhetoric of counsel in early modern England," in Tudor Political Culture, ed. Dale Hoak (1995), 292; Jacqueline Rose, "The problem of political counsel" in The Politics of Counsel in England and Wales 1286-1707, ed. Jacqueline Rose (2016), 6.

${ }^{30}$ Paul, "Serving the public", 40.

${ }^{31}$ Quentin Skinner, The Foundations of Modern Political Thought Volume One (1978), 193-243.

32 Desiderius Erasmus, The Education of a Christian Prince [1516] (1997), 6.

33 Thomas Elyot, The Boke Named the Governor [1531] (2010), 241.

${ }^{34}$ Stella Achilleos, "Friendship and good counsel: the discourses of friendship and parrhesia in Francis Bacon's the Essayes or Counsels, Civil and Moral," in Friendship in the Middle Ages and Early Modern Age: Explorations of a Fundamental Ethical Discourse, eds. Albrecht Classen and Marilyn Sandidge (2010), 661.

35 Ibid., 661.
} 
and unseemly conduct, when presented in a suitably timely way. Recent scholarship thus confirms the importance of the concept of the kairos - the right or opportune moment - to the enactment of parrhesia, extensively discussed in the later lectures. ${ }^{36}$

Recent historiography also confirms the radical challenge to the ideal of the frank speaking counsellor presented by Machiavellian discourse after the publication of The Prince, which circulated widely in England from the 1580s. ${ }^{37}$ The figure of the counsellor, on this interpretation, was an artful and corrupt actor. And private counsel was commonly a dangerous encounter for a ruler, especially in England, for the youthful and female monarchs of the later Tudor dynasty. ${ }^{38}$ A related critique of the corruption of those who sought to advance personal and private interests in giving counsel informed the thought of both Machiavellians and those influenced by the emerging discourse of reason of state, such as Francis Bacon. ${ }^{39}$ Ultimately, for Bacon, the record of history - and the testimony of the deceased - was a surer guide to the uncertainty and risks of political life and the enhancement of the military and political strength of the state. Similarly, institutionalised counsel, through a council of state or Parliament, was also increasingly recommended as a more reliable source of counsel, as the comparative observation of societies came to be viewed as the basis of political knowledge. Later, in the pre-revolutionary period, the concept of the evil Machiavellian adviser who, in pursuit of their own ends flattered the monarch rather than speaking with parrhesia, informed the political disputes of the time, as the Parliamentarian side claimed a right not only of counsel but of consent in their relations with the monarch as custodians of the interests and reason of the state. ${ }^{40}$ Recent historiography has therefore confirmed the tensions in modes of political truth-telling in the early modern period in Britain, as the ideal of frank counsel competed with alternative and widely known Machiavellian notions.

\section{ON THE BIRTH OF BUREAUCRATIC FRANK COUNSEL}

Paul' ${ }^{41}$ recent account suggests a fading of the relevance of parrhesia in Britain after the Civil Wars that concluded in 1651 with the refashioning of political discourse to address the problem of sovereignty and changing relations between the monarchy and parliament. Here, however, we propose another, later revival in Britain of the ideal of parrhesia in a political context. The setting was the debate in the middle decades of the nineteenth century over the organisation of the offices of government and the requisite 'character' of the British public servant in a liberal Parliamentary regime, led by an alliance of prominent educational reformers, politicians and public servants. As Joyce ${ }^{42}$

\footnotetext{
${ }^{36}$ Foucault, Hermeneutics of the Subject, 388; Government of Self and Others, 224.

${ }^{37}$ Niccolò Machiavelli, The Prince [1513] (1993).

38 Paul, Counsel and Command, 11.

${ }^{39}$ Francis Bacon, Of Counsel [1597] (2010).

${ }^{40}$ Counsel and Command, 195.

${ }^{41}$ Ibid., 203.

42 Patrick Joyce, The State of Freedom (2013), 190.
} 
shows, these years were marked by intense controversy over the organisation of the administration of government. In part, the argument centred on the growing costs of government and the inefficiency of a system that continued to rely heavily on patronage in relation to the recruitment and advancement of public servants. For some, however, the problematic condition of the offices of government formed part of a broader critique of the condition of liberal politics and society, requiring major reform not only of the organisation of administration but a reprogramming of the identity of public servants.

For the alliance of reformers that helped to fashion the core values and practices of a new 'intellectual' class of public servants, the provision of counsel or advice was named as the first function of the civil servant. ${ }^{43}$ To the principles of the division of labour, recruitment on merit and the idea of bureaucracy as a vocation, which owed much to the system of administration in the Indian Civil Service, ${ }^{44}$ the reformers added the ideal of a senior administrative class possessed with a deep sense of the interests of the public domain and a certain 'independence' of character.

What Thomas Osborne ${ }^{45}$ terms the 'romance' of Indian bureaucracy was of decisive importance to these developments: the ideal of the administrator governed by a calling and owing nothing to the vagaries of patronage. Foucault ${ }^{46}$ suggested that the colonising practices of the European powers should be viewed not only in terms of the transportation of political weapons to other continents but in terms of a 'boomerang' effect on the mechanisms of power in the West. On this interpretation, the British experience in India provides one particularly vivid illustration of the point being made.

Historians of Victorian Britain have also taken Samuel Taylor Coleridge as a key inspiration for the reformers' ideal of a liberally educated and deeply moral class of public servants. ${ }^{47}$ Defending a Platonised version of Christianity and borrowing extensively from German romantic thought, Coleridge envisaged ideal social orders as founded on the opposing forces of progress and permanence, ${ }^{48}$ a balance he believed had gone awry in the singular circumstances of late eighteenth and early nineteenth century England. ${ }^{49}$ Not least as a function of the influence of the atomistic and mechanistic logic of the theories of political economy and empiricist philosophy, the aristocratic interest had abandoned traditional social duties. The members of a new 'clerisy', including the learned of all denominations - educators, theologians and Oxbridge educated scholars - were to preserve civilisation in a free society. They were also to manifest a vigorous and 'manly' independence of judgement and frankness of

\footnotetext{
43 Parliamentary Papers (PP) (1854), 2.

${ }^{44}$ Richard Chapman and J.R. Greenaway, The Dynamics of Administrative Reform (1980); Thomas Osborne, "Bureaucracy as a vocation," Journal of Historical Sociology 7 (1994), 289-313; Edward Barratt, "Governing public servants," Management and Organizational History 4:1 (2009), 72.

45 Osborne, "Bureaucracy as a vocation," 294.

${ }^{46}$ Michel Foucault, Society Must Be Defended [1997] (2003), 103.

47 Peter Gowan, “The origins of the administrative elite," New Left Review 162 (1987), 24.

48 Samuel Taylor Coleridge, On the Constitution of Church and State [1839] (2015), 24.

${ }^{49}$ Harold Perkin, The Origins of Modern English Society [1969] (2002), 308-318.
} 
speech in the manner of the Apostles of Christ and, most especially, St Paul. ${ }^{50}$ The same virtues were also understood to be those of the ancient Greeks and, most especially, Socrates, ${ }^{51}$ lionised by the educated Victorians as a secular Christ. ${ }^{52}$ Particularly for Benjamin Jowett - the Oxford classicist and intellectual leader of the alliance of reformers - the ancient Greeks and the British shared a common cultural trajectory. ${ }^{53}$ Jowett, however, believed that an educated Victorian Christian elite were perfecting and purifying the values of civilisation.

A new 'intellectual' class of public servants would serve as exemplary moral subjects for a ruling class that had abandoned its customary sense of duty in favour of an acquisitive morality, in a society the reformers considered to have been rendered unstable by the forces of economic progress. ${ }^{54}$ Yet though they accepted Coleridge's political analysis of the effects of an overbearing spirit of capitalism, much more than the simple application of a Coleridgean logic was at stake in the polyvalent logic of the midnineteenth century reformers. Coleridge intended the 'clerisy' only to be a moral force in civil society rather than entering the political domain. For the British Civil Service reformers, a new 'intellectual' class of liberally educated gentlemen, recruited on merit, would also bring efficiency to administration at a time of economic pressure, as well as a new purity to political and social life. By such means, the stability and security of a free society would be preserved.

A certain way of governing public servants can be seen, therefore, as an attempt to address a number of characteristically classical liberal problems of rule: to secure the normal and natural form of life of an autonomous domain of civil society - but in a manner that was intended to eclipse Benthamite utilitarian prescriptions, which were fashionable in the 1830s and 1840s.55 Close to the reformer's ideal of a new class of 'manly' ruling subjects was the aspiration of another governmental scheme in Britain in this period, specifically that of the well-known 'public school' headmaster Thomas Arnold at Rugby School, beginning in the late 1820s. Arnold ${ }^{56}$ envisaged Rugby School as a liberal social order in its own right: a self-regulating mechanism and a context in which the natural condition of boyhood - with vicious and indolent tendencies - could be passed through in a way that accelerated the transition to Christian manhood. Arnold's prefectorial class of the school were to be exemplary individuals endowed with functions of government well beyond their years. Seeking to fashion through these senior pupils not merely fighting Christians but thinking ones, the youth of the aristocracy and the upper middle class were to be encouraged to learn to assemble their

\footnotetext{
${ }^{50}$ William Winn, "Tom Brown's schooldays and the development of muscular Christianity," Church History 29:1 (1960), 64-73; Norman Vance, The Sinews of the Spirit (1985), 26; Courage of Truth, 330.

${ }^{51}$ Frank M. Turner, The Victorians and Ancient Greece (1980), 415.

${ }^{52}$ Mark Stopper, “Greek Philosophy and the Victorians,” Phronesis 26:3 (1981), 279.

53 Turner, Victorians and Ancient Greece, 419; Benjamin Jowett, "Introduction," in Plato, Charmides [1871]

(2019), 18.

${ }^{54}$ Coleridge, Constitution of Church and State, 46.

55 Gowan, "The Origins of the Administrative Elite," 10.

${ }^{56}$ Arthur Penrhyn Stanley, Stanley's Life of Arnold [1840] (1895), 111-125.
} 
own opinions and become self-regulating Christian subjects schooled in the timeless truths of the ancients and the critical appreciation of the scriptures. The mid-nineteenth century Civil Service reformers' image of the thinking public servant, willing to tell the truth to power, could be said to owe much to an interpretation ${ }^{57}$ of Arnold's experiment at Rugby school that was widely read by sections of the ruling aristocratic elite in the 1840s, especially at Oxford. In both instances, a key aim was to fashion a new class of manly, frank speaking ruling subjects fit to govern a troubled liberal society.

The programmatic ideals of the mid-nineteenth century reformers took many years to come to fruition as they were frustrated by a lack of political support and from within the Civil Service, especially the Treasury, who feared the scheme would lead to undue expense. ${ }^{58}$ Much later, however, the first head of the modern British Civil Service ${ }^{59}$ expressed the same ideal of frank counsel. The civil servant had by now been separated from the party-political game that developed during the later decades of the nineteenth century and become an anonymous figure subordinated to a minister as a policy adviser in the new expanded state. ${ }^{60}$ Rationalised by the threat of war and the fear of spies, new standards of strict confidentiality had developed, governing the relationship between an adviser and a ministerial head. ${ }^{61}$ In the style of his intellectual mentor, the Hegelian Viscount Haldane, Warren Fisher ${ }^{62}$ imagined the Civil Service in a holistic way: an ideal to be made real through mechanisms of interdepartmental movement and service-wide recreational activity, complementing the role of everyday departmental life in reinforcing the collective knowhow of a department. ${ }^{63}$ Fisher understood the civil servant as guided by principles and precepts that could not be elaborated into any 'detailed code' and for which the most effective sanction was the public opinion of the Civil Service itself. But what distinguished the character of the civil servant in this view was an integrity, fearlessness and independence of thought. In later life, responding to what he took to be the growing Americanisation of political life in Britain, Fisher revisited the theme of bureaucratic frank counsel. Civil servants, he said, should respond to any ministerial 'shady dealing' by stating clearly 'this is a damn swindle sir and you can't do it'. ${ }^{64}$ An element of detachment was nonetheless at the heart of this ethical scheme. As his disciple Edward Bridges ${ }^{65}$ in the 1950s stated, a civil servant was consumed with an 'ardour' for the scholarly chase in addressing a policy problem, unwilling to be swayed by preconceptions or prejudices, in a style reminiscent of the Oxbridge don. Whilst there was always a place for specialists in the work of government, the practice of the administrator was of a different order: the capacity to

\footnotetext{
57 Ibid.

${ }^{58}$ Chapman and Greenaway, Dynamics of Administrative Reform, 43-69; Rodney Lowe, The Official History of the Civil Service (2011), 18-41.

${ }_{59}$ Warren Fisher to Lord Tomlin, Royal Commission on the Civil Service 1929-1931 (1931), 1268, para 12.

${ }^{60}$ Rose, Powers of Freedom, 120.

${ }^{61}$ David Vincent, The Culture of Secrecy (1998), 134.

62 Richard Haldane, “An organized Civil Service," Public Administration 1:1 (1923), 6-16.

63 Joyce, State of Freedom, 187.

${ }^{64}$ Warren Fisher quoted in Barry O'Toole, The Ideal of Public Service (2006), 77.

${ }^{65}$ Edward Bridges, "The reforms of 1854 in retrospect," Political Quarterly 25:4 (1954), 321.
} 
see the essential points and facts in a situation, to understand preconditions and implications and to anticipate future circumstances.

Parrhesia, then, has a place as a transplant or graft in the history of the fabrication of a particular scheme of bureaucratic ethics. Ideas originally associated in England with a 'republican monarchist' public service discourse, exemplified by advisers of the monarchy, such as Thomas More ${ }^{66}$ or Thomas Elyot, ${ }^{67}$ subsequently became part of an ethical regime associated with the senior public servant in a liberal Parliamentary regime. Indeed, the ideal of the senior official as a free and frank adviser anonymous and subordinate to a minister of state, accountable to an elected Parliament in a permanent, politically non-partisan civil service, subsequently became an element of the so called 'Westminster' system of Parliamentary government. The system was 'exported' by the British to many of the former colonies of the British Empire, ${ }^{68}$ with the so-called self-governing dominions of Canada, New Zealand and Australia generally understood to be closest to British practice.

\section{NEOLIBERALISM, FRANK COUNSEL AND THE ‘MANDARINS’ OF THE BRITISH CIVIL SERVICE}

How, then, can we conceptualise the fate of bureaucratic frank counsel in Britain in our own era? Interpreters of Foucault's later lectures on neoliberalism have shed light on the shifting rationalities and technologies for the government of public servants. ${ }^{69}$ On this interpretation, the practice of frank counsel in the British Civil Service would appear to have been eclipsed, with the generalisation of virtues and practices associated with the domain of enterprise to the domain of administration and with the pursuit of more 'responsive' government, displacing an ethics of public 'responsibility'. There is a long history of the deployment of management methods in the Civil Service in the 1960s and 1970s. ${ }^{70}$ But for leading interpreters, the era of Conservative rule under the leadership of Margaret Thatcher, beginning in 1979, marks a decisive moment of change with the wholehearted pursuit of business-like and politically responsive administration. The varied forms of neoliberal thought, documented in Foucault's preliminary and primarily textual analysis and evaluation of the emergence of German and American neoliberal reason, ${ }^{71}$ now began to find concrete technological expression.

\footnotetext{
66 Thomas More, Utopia [1515] (2012) 27.

${ }^{67}$ Thomas Elyot, The Boke Named the Governor [1531] (2010), 241.

${ }^{68}$ Rhodes, Wanna and Weller, Comparing Westminster, 1-20.

${ }^{69}$ Barry, Osborne and Rose, “Introduction," 1-19; Powers of Freedom, 150.

${ }^{70}$ Lowe, Official History of the Civil Service, 81-129.

71 Michel Foucault, The Birth of Biopolitics [2004] (2008), 322-324; Mitchel Dean, "Foucault. Ewald, neoliberalism and the left," in Foucault and Neoliberalism, eds. Daniel Zamora and Michael Behrent (2016), 94-97; Nicholas Gane, “The emergence of neoliberalism,” Theory, Culture and Society 31:4 (2014), 3-27.
} 
Critics inspired by the concept of governmentality ${ }^{72}$ allude to 'core NPM ideas' closely related to the Chicago variant neoliberalism, though not directly addressed by Foucault - deriving from public choice theory and organisational economics and underpinning the market-orientated reform doctrines of this time. The Conservative criticisms of bureaucracy certainly bore the mark of the work of William Niskanen ${ }^{73}$ on bureaucracy, first published by the thinktank: The Institute of Economic Affairs (IEA) in the early 1970s. From the early 1960s, the IEA played an important role in advancing neoliberal discourse in the Conservative Party, providing a forum for neoliberal elements of the Conservative Party to publish their own work, advancing new schemes for privatising and remodelling state institutions. But with the publication of Niskanen, new forms of neoliberal critique were being made available. Counsel in the name of the 'public interest', it was claimed, occluded the real ambitions of senior bureaucrats to expand their own budgets and departments, ultimately for their own economic benefit, at the expense, Conservatives argued, of those who produced wealth, ${ }^{74}$ the taxpayer ${ }^{75}$ and the income of the nation.

Yet as they entered government in 1979, the Conservatives' critique of the senior civil servant as a counsellor to a minister of state took a number of forms, and by no means all of a piece. ${ }^{76}$ The senior bureaucrat, it was claimed, never felt the pressure and discipline of the market with the dynamism, creativity, flexibility and value for money that it encouraged. At the same time, his or her frank counsel amounted to an interference with the will of government. Criticism of this type commonly drew on an interpretation of the Conservatives' experience of government in the early 1970s, especially the years 1972-1974. In a narrative of betrayal, ${ }^{77}$ Conservatives argued they had entered government in 1970 with a clear plan to advance enterprise and curb the size and powers of the state, only to be outmaneuvered and thwarted by officials who defended an institutionally defined view of the public interest on key policy questions. The account of betrayal, as others, such as Green, have argued, ${ }^{78}$ exaggerated the degree to which neoliberal orthodoxy had the wholehearted support of the party's leadership or assumed a coherent form as a practical scheme of rule in the later years of the 1960s. Nonetheless, it provided an important resource for mobilising support and encouraging action to refashion bureaucracy after 1979 .

Drawing on his experience in the 1960s and 1970s, the former senior civil servant Christopher Foster ${ }^{79}$ presents a vivid account of the routines of administrative life: the meticulous minuting and maintenance of files through which policy was made and

\footnotetext{
72 Ewan Ferlie and Gerry McGivern, "Bringing Anglo-governmentality into public administration scholarship", Journal of Public Administration Research and Theory 24:1 (2013), 60.

${ }^{73}$ William Niskanen, Bureaucracy: Servant or Master? (1971), 33.

${ }^{74}$ Robert Bacon and Walter Eltis, Britain's Economic Problem: Too Few Producers (1978), 28-31.

${ }^{75}$ Conservative Central Office, Conservative Manifesto (1979), 2.

76 Powers of Freedom, 151.

77 Ewen H. H. Green, Ideologies of Conservatism (2002), 214-239.

${ }^{78}$ Ibid.

${ }^{79}$ Christopher Foster, British Government in Crisis (2005), 26.
} 
remade and the close working and personal relationships between ministers and officials in which frank counsel and personal support was given. For the Thatcher government, such routines of administrative life had not only contributed to an unsustainable expansion of the State, national indebtedness and economic failure; they also threatened the course of radical change. Policy decisions, Margaret Thatcher argued, should be a matter for politicians alone. ${ }^{80}$ Senior bureaucrats should therefore abandon their proclivity for frank counsel - all too often a way of coding obstruction to government schemes which differed from departmental orthodoxy. ${ }^{81}$ Instead, they should pursue an attitude of vigorous, 'can do' enthusiasm in the implementation of policy and the pursuit of efficient and business-like administration.

Informed by these varied critiques in the early years of government, Conservatives set out to address the costs, size and 'privileges' of bureaucracy, introducing new norms of pay comparability and substantial reductions in the number of officials - including in the most senior grades. A new system of departmental review was then introduced that was designed to encourage 'cost consciousness'. Departments were to identify sources of waste and inefficiency on their own initiative, with junior officials, rather than departmental heads, taking the lead in the scrutiny process. A new Efficiency Unit, led by a senior businessman, initiated and oversaw the review process, typifying the growing reliance on business advisers at the centre of government. At the same time, there was a new concern shown by politicians with promotions at the very top of the Civil Service - which officials were to advance to the highest levels became a matter of ministerial interest, breaking with the convention that recommendations for promotion should generally be approved without political intervention. It was not political sympathy that was at stake in these key decisions but rather a matter of disposition and attitude: evidence of appropriate concern with efficiency, management and the implementation of policy in those who were to progress to the most senior levels. Margaret Thatcher believed this sent a powerful message to lower levels in the bureaucracy about the new priorities. Nonetheless, for all the changes introduced by the Conservatives during these years, Rose's notion of a messy and often compromised 'lash up of thought and action' captures the haphazard way in which measures of economy and efficiency were pursued during the early years of Margaret Thatcher's government. ${ }^{82}$

\section{IN DEFENCE OF FRANK COUNSEL}

Yet, as we see it, there would seem to be good grounds for qualifying any simple appraisal of the eclipse of bureaucratic frank counsel in this period. Further consideration of the early years of the neoliberal government of public servants suggests

\footnotetext{
${ }^{80}$ Margaret Thatcher, The Downing Street Years (1993), 46.

81 Paul du Gay, "In defence of mandarins; recovering the core business of public management," Management and Organizational History 4:4 (2009), 74.

82 Powers of Freedom, 151.
} 
a number of significant counter-tendencies. Analysts ${ }^{83}$ inspired by Foucault's lectures on neoliberal governmentality have hitherto said little of the varied forms of resistance that developed within the Civil Service at this time, thereby encouraging the charge of determinism and fatalism commonly levelled against them. ${ }^{84}$ Resistance to the Conservatives took a variety of forms. There was organised resistance in the form of a twenty-one week industrial dispute, as the pursuit of economy and the attempt to 'deprivilege' civil servants undermined policies of pay comparability with the private sector. ${ }^{85}$ Beginning with the case of a civil servant disclosing documents on a matter of national defence - appearing to suggest a minister planning to avoid accounting for his actions before Parliament - there were several cases of civil servants leaking official documents to the press. ${ }^{86}$ These cases generally involved officials at lower levels in the hierarchy who, in the everyday routines of the central bureaucracy - the copying of a memorandum or the preparation of a report - found evidence of practices that called into question their responsibility to uphold the public interest.

Of particular relevance for this discussion, a number of senior bureaucrats now spoke up in defence of the customary ethics of their profession, with the defence of frank counsel at the centre of the argument. Disturbing customary norms of privacy, the dispute with the Conservatives at times became public as a small group of officials, approaching retirement, spoke candidly in defence of bureaucratic frank counsel. ${ }^{87}$ The Head of the Civil Service famously spoke up to Margaret Thatcher on a number of occasions, challenging both economic arguments favoured by the Conservatives and what he interpreted as a threat to the norms of the Civil Service. Civil servants, he said, had become too willing to flatter the Conservatives, providing advice that they wanted to hear. The 'grovel count' in the Civil Service had been high during these years, as he put it in a later interview. 88 There was an absence of what another senior official referred to as a corrective approach whereby a civil servant could counsel a minister against constitutional impropriety or unwise and short-term policy measures. ${ }^{89}$ The Head of the Civil Service's questioning of the condition of the ethics of his profession was soon followed by others querying if there was now a need for a new formality of approach. ${ }^{90}$ For some, at least, it appeared that the Civil Service could no longer rely on the organisation's customary informal self-discipline.

Specific features of a new ethical technology to protect bureaucratic ethics and frank counsel were proposed in the aftermath of a notorious legal case in this era. Clive

\footnotetext{
${ }^{83}$ Ibid., 150.

${ }^{84}$ Pat O'Malley, Lorna Weir and Clifford Shearing, "Governmentality, criticism, politics," Economy and Society 26:4 (1997), 501-527.

${ }^{85}$ Lowe, Official History of the Civil Service, 265.

${ }^{86}$ Geoffrey Fry, "The development of the Thatcher government's grand strategy for the Civil Service," Public Administration 62:3 (1984), 326.

87 Douglas Wass, “The public service in modern society," Public Administration, 61:1 (1983a), 14; Hugo Young and Ann Sloman, No Minister (1982), 31.

${ }^{88}$ Ian Bancroft, quoted in David Marquand, The Decline of the Public (2004), 109-110.

89 Brian Cubbon, quoted in Young and Sloman, No Minister (1982), 31.

${ }^{90}$ Douglas Wass, Government and Governed (1983b), 51.
} 
Ponting, a senior official at the Ministry of Defence, supplied documents to a Labour MP disclosing that, contrary to information provided to Parliament by the Government, the sinking of an Argentine ship during the Falklands War had breached the rules of engagement. Charged under the Official Secrets Act of 1911, Ponting ${ }^{91}$ claimed that he had been acting in the public interest with a higher loyalty in mind than that of his minister and the government of the day. He had attempted to speak up and air his concerns only to be ignored. The judge, in directing the jury, argued instead that the public interest was as the government of the day determined it to be. The jury, after brief deliberation, acquitted Ponting, accepting his argument that he had indeed been acting with the public interest in mind.

At stake in Ponting's defence was the ideal of the civil servant as an impartial and independent adviser to government; not only as a loyal servant of the government of the day but a truth-teller endowed with a deep sense of the public interest. After the case, the staff association representing senior civil servants intervened, seeking to clarify the issues at stake. The Head of the Home Civil Service argued that if a matter of conscience was involved, a civil servant should consult his superiors, and if the issue could not be resolved, he or she should resign from the Civil Service. For the staff association, this was too limited a view of the duties of a civil servant. ${ }^{22}$ Civil servants had rightly been the custodians of their own largely unwritten professional values and comportments. But an effective response to what the FDA judged to be a fundamental change of circumstances now required a new formality of approach: a new code of conduct to clarify and reinforce the duties of civil servants as subjects of integrity and bearers of the public good. The setting or scene for acts of bureaucratic truth-telling to a politician would generally continue to be private. But there should be a new right of appeal to an independent body that a senior bureaucrat could activate specifically in circumstances where conscience prevented her or him from serving government or where the implementation of policy would entail an infraction of the law. Not only should a particular bundle of ethical comportments be precisely inscribed, a set of supporting and enabling practices and procedures should be detailed to enable their attainment.

Ponting, after his trial, spoke of a fundamental and standing interest of the public requiring an ethical code. ${ }^{93} \mathrm{~A}$ code, inscribing standards, would clarify the duties of the civil servant: what he or she should be expected to undertake and to do if he or she believed that the government was doing something morally wrong or illegal. It would help to correct a tendency that had developed under the Conservatives; namely, the expectation that senior civil servants act as advocates of policy rather than advise openly and candidly. Ponting was effectively repeating the claims of the staff association. But the issues raised by the case served to contribute to a wider debate. Intellectuals and journalists now showed an increasing willingness to speak up on behalf of civil

\footnotetext{
${ }^{91}$ Clive Ponting, The Right to Know (1985), 2-6.

92 First Division Association, "Civil servants' duties and responsibilities," Seventh Report of the Treasury and Civil Service Select Committee, 1985-1986, HC 92-11.

${ }_{93}$ Clive Ponting, Whitehall: Tragedy and Farce (1986), 240.
} 
servants. ${ }^{94}$ Again, civil servants entered the debate. The remedies for reinforcing frank counsel were now at the centre of a political argument, with a demand for ethical codification at the fore. ${ }^{95}$

And yet, Ponting - whose case had inspired this controversy - was a contradictory figure. He had been praised by Margaret Thatcher for his work on one of the reviews of the new Efficiency Unit, examining food supply to the military and presenting his recommendations for efficiency gains to senior ministers. In the years following the case - and before beginning an academic career as an historian - Ponting wrote critically on the organisation and management of the Civil Service. ${ }^{96}$ Ponting's analysis and programmatic prescriptions shared much in common with those of the Conservatives, anticipating developments in the later 1980s and early 1990s. ${ }^{97}$ Both Ponting and the initiators of the later Conservative reforms shared the sense that management had been devalued in favour of high-status policy work. Such reforms as had been attempted were piecemeal and overly concerned with economy rather than efficiency and effectiveness from the customer's point of view. There had been insufficient interchange of personnel between the public and private sectors. Too little attention had been given to skill development in a system that relied excessively on workplace-based training, reinforcing the 'inward looking' nature of the Civil Service. Anticipating the reforms of the later 1980s, ${ }^{98}$ in Ponting' $\mathrm{s}^{99}$ preferred structure, there would be a separation of policy and management with newly established agencies responsible for implementing policy in accordance with central directives but independent of central government. Each agency would be led by a chief executive with the real autonomy required to manage effectively, enable recruitment, implement appropriate incentives and variations in reward management and reflect local needs and circumstances.

Perhaps then, in conclusion, there are two ways in which we can interpret the significance of this moment of resistance in the era of Margaret Thatcher for subsequent developments. On the one hand, we have what appears to be a break or rupture in the turn towards the ideal of codifying frank counsel; an episode in the long, varied and 'spidery' history of the notion of parrhesia in a political setting - a history that Foucault began but was unable to develop. ${ }^{100}$ Beginning with the intervention of senior civil servants and their staff association in the 1980s, we witness a moment in the emergence of the very idea of codifying bureaucratic frank counsel. As we have seen, for prominent civil servants of the past, the acquisition of practical knowhow and understanding was more effectively acquired by the material practices of bureaucratic work. In changed political conditions, frank counsel had become an element in a scheme to inscribe the

\footnotetext{
${ }^{94}$ William Plowden, What Prospects for the Civil Service? (1985), 9.

${ }^{95}$ Edward Barratt, 'Speaking frankly', Management and Organizational History, 14: 3 (2019): 303.

${ }^{96}$ Ponting, Right to Know, 2-7; Ponting, Whitehall: Tragedy and Farce, 1-18.

${ }_{97}$ Kate Jenkins, Karen Caines and Andrew Jackson, Improving Management in Government: The Next Steps (1988), 9; Prime Minister, The Civil Service: Continuity and Change (1994), 1-6.

98 Jenkins, Caines and Jackson, Improving Management in Government, 15.

${ }^{99}$ Whitehall: Tragedy and Farce, 187-225.

100 Government of Self and Others, 45.
} 
ethical conduct of public servants - and, for the first time, this was an objective shared by an array of political actors. Years would pass before a formal ethical code for the Civil Service would be endorsed by the leaderships of the major political parties. But when the political parties agreed in 2010 on the need for the formal inscription of a set of core bureaucratic ethics - integrity, honesty, objectivity and impartiality - in a code to have legal force, ${ }^{101}$ senior civil servants, resisting reform in the early years of neoliberal rule in Britain, appear to have played a decisive part in the struggle.

Yet, as we have seen, Ponting also imagined - in his scheme for the management of the Civil Service - another, quite different configuration of power relationships; one that would further extend practices associated with the domain of enterprise to the domain of administration. As such, his arguments appear vulnerable to a number of familiar criticisms: that, under agency-based administration, there would be an attenuation of political accountability and a weakening of policy making when 'implementation' and 'policy' were seen as separate processes. ${ }^{102}$ Of most relevance to this discussion, Ponting failed to address the problem of how the proposed code would sustain and protect the values of public service when the material practices of working life were designed to encourage virtues of another kind - that of enterprise - in a newly incentivised and restructured Civil Service with a growing number of external appointments.

In his ambivalence, we would suggest that Ponting anticipates a common tendency in our own era, namely that of endorsing core bureaucratic values and an associated code of ethics, fortified by the law, whilst seeking to advance and extend practices that undermine those same values. Thus, under the Conservative dominated alliance in the years 2010-2015, there is evidence of an increased use of political appointees leading the processes of policy development and implementation, ${ }^{103}$ as the seemingly friendlier tone of early messages to senior officials about respecting their candid advice gave way to criticism of their obstructiveness and lack of enterprise. ${ }^{104}$ Newly configured departmental boards now played a critical part in the processes of government. The 'non-executive' board member - political appointees working at the heart of the administration and drawn primarily from the business interest - not only supplied the necessary strategic guidance and knowhow but played a part in determining the fate of the senior civil servant. Civil servants unable to demonstrate the necessary commitment to political priorities would now be at risk of replacement on the recommendation of the 'non-executives'.

After 2016, with new political leadership, critics speak of 'court government', led by two politically-appointed Chiefs of Staff, and a general marginalisation of civil servants in key decisions. Yet expressions of support for the customary practice of frank counsel

\footnotetext{
${ }^{101}$ Gordon Brown, “Constitutional reform statement," [2007] in The Change We Choose (2010), 162; Francis Maude, Speech at Civil Service World Conference (2009a); Francis Maude, Conference Speech (2009b).

102 Richard Chapman and Barry O'Toole, "The role of the Civil Service: a traditional view in a period of change," Public Policy and Administration 10:2 (1995), 3-20.

103 Patrick Diamond, The End of Whitehall (2018), 1-116.

${ }_{104}$ David Cameron, Speech at Conservative Party Forum, March 2011.
} 
and a supporting code of ethics by political leaders continued. ${ }^{105}$ Although it is beyond the scope of the present discussion to evaluate such a viewpoint, such a 'courtly' style of administration would, for some, be indicative of the so-called 'new public governance' (NPG) as a mode of administration directed strategically from the centre and adjusted to an era of permanent political campaigning. ${ }^{106}$ In such an approach, politicians assign paramount importance to the presentation and promotion of government policy; a practice in which the senior bureaucrat becomes a key agent. Yet, as the theorists of the NPG argue, such developments commonly take place in combination with formal political support for the customary ethics of public service - including frank counsel enshrined in a code of ethics. ${ }^{107}$

Without genuine and consistent political support, then, a code must be, as it is today, essentially a weak tactical supplement to the pursuit of other goals: politically responsive administration with managerially defined standards of performance. ${ }^{108}$ If bureaucratic frank counsel remains, as du Gay ${ }^{109}$ argues, an essential 'constitutional ballast' in a particular Parliamentary democratic state regime - and an essential condition for the nurturing of political truth-telling in that regime ${ }^{110}$ - support for this practice on the part of those who govern, in both word and deed, is an essential condition of its effectiveness. We conclude this discussion, therefore, with an argument that resonates with ancient ideals that we have been considering.

\section{References}

Achilleos, Stella, 'Friendship and good counsel: the discourses of friendship and parrhesia in Francis Bacon's The Essayes or Counsels, Civill and Morall,' in Friendship in the Middle Ages and Early Modern Age: Explorations of a Fundamental Ethical Discourse, eds. Albrecht Classen and Marilyn Sandidge, 643-74. Berlin: de Gruyter, 2010.

Aucoin, Peter, “New political governance in Westminster systems," Governance 25:2 (2012), 177-199. https://doi.org/10.1111/j.1468-0491.2012.01569.x

Bacon, Francis, Of Counsel [1597]. Charleston, South Carolina: BiblioBazaar, 2010.

Bacon, Robert, and Walter Eltis, Britain's Economic Problem: Too few producers. London: Macmillan, 1978.

Bakvis, Herman, and Mark Jarvis, From New Public Management to New Political Governance: Essays in Honour of Peter Aucoin. Montreal: McGill Queens Press, 2012.

Barratt, Edward, "Governing public servants," Management and Organizational History 4:1 (2009), 67-84. https://doi.org/10.1177/1744935908098859

\footnotetext{
${ }^{105}$ Diamond, End of Whitehall, 6.

106 Aucoin, "New public governance in Westminster systems," 179; Herman Bakvis and Mark Jarvis, From the New Public Management to New Public Governance: Essays in Honor of Peter Aucoin (2012), 1-28.

107 “New public governance in Westminster systems," 189.

108 Peter Triantafillou, Neoliberal Power and Public Management Reforms (2017), 151.

109 du Gay, "In defence of mandarins," 373.

110 Whitehall: Tragedy and Farce, 1-18.
} 
Barratt, Edward, "Speaking frankly," Management and Organizational History 14:3 (2019), 294310. doi/abs/10.1080/17449359.2019.1698439

Barry, Andrew, Thomas Osborne, and Nikolas Rose, "Introduction," in Foucault and Political Reason, eds. Andrew Barry, Thomas Osborne and Nikolas Rose, 1-19. Chicago: Chicago University Press, 1996.

Bridges, Sir Edward, "The reforms of 1854 in retrospect," Political Quarterly 25:4 (1954), 316323. https://onlinelibrary.wiley.com/doi/abs/10.1111/j.1467-923X.1954.tb01766.x

Brown, Peter, Power and Persuasion in Late Antiquity. Madison: University of Wisconsin Press, 1992.

Brown, Gordon, “Constitutional reform statement" [2007], in The Change We Choose, 159-182. London: Mainstream, 2010.

Cameron, David, Speech at Conservative Spring Forum. Cardiff, March, 2011.

Chapman, Richard, and J. R. Greenaway, The Dynamics of Administrative Reform. London: Croom Helm, 1980.

Chapman, Richard, and Barry O'Toole, "The role of the Civil Service: a traditional view in a period of change," Public Policy and Administration 10:2 (1995), 3-20. https://doi.org/10.1177/095207679501000202

Colclough, David, Freedom of Speech in early Modern England. Cambridge: Cambridge University Press, 2005.

Coleridge, Samuel Taylor, The Collected Works of Samuel Taylor Coleridge: On the Constitution of Church and State [1839]. Princeton, NJ: Princeton University Press, 2015.

Condren, Conel, Argument and Authority in Early Modern England. Oxford: Oxford University Press, 2006.

Conservative Central Office, Conservative Manifesto [1979]. Margaret Thatcher Foundation, 2020. https://www.margaretthatcher.org/document/110858.

Dean, Mitchell, "Foucault, Ewald, Neoliberalism and the Left," in Foucault and Neoliberalism, eds. Daniel Zamora and Michael Behrent, 85-114. Cambridge: Polity, 2016.

Diamond, Patrick, The End of Whitehall. Basingstoke: Palgrave, 2018.

Du Gay, Paul, "In defence of mandarins: Recovering the 'core business' of public management," Management \& Organizational History 4:4 (2009), 359-384.

https://doi.org/10.1177/1744935909342326

Elyot, Thomas, The Boke Named the Governor [1531]. Cambridge: ProQuest EEBO Edition, 2010.

Erasmus, Desiderius, The Education of a Christian Prince [1516]. Cambridge: Cambridge University Press, 1997.

Ferlie, Ewan, and McGivern, Gerry, "Bringing Anglo-governmentality into public ad ministration scholarship," Journal of Public Administration Research and Theory 24:1

(2014), 59-83. https://doi.org/10.1093/jopart/mut002

Foster, Christopher, British Government in Crisis. London: Bloomsbury, 2005. 
Foucault, Michel, Fearless Speech. New York: Semiotext(e), 2001.

Foucault, Michel, Society Must Be Defended [1997]. New York: Picador, 2003.

Foucault, Michel, The Hermeneutics of the Subject [2001]. Basingstoke: Macmillan, 2005.

Foucault, Michel, "What is critique?" [1978], in What is Enlightenment?, ed. J. Schmidt, 382399. Berkley: University of California Press, 1996.

Foucault, Michel, Society, Territory, Population [2004]. Basingstoke: Macmillan, 2007.

Foucault, Michel, The Birth of Biopolitics [2004]. Basingstoke: Macmillan, 2008.

Foucault, Michel, The Courage of Truth [2008]. Basingstoke: Macmillan, 2011.

Foucault, Michel, The Government of Self and Others [2008]. Basingstoke: Macmillan, 2010.

First Division Association, Memorandum submitted to the Treasury and Civil Service Committee: "Civil servants' duties and responsibilities", in Seventh Report of the Treasury and Civil Service Select Committee Session 1985-6, HC 92- 11. London: HMSO, 1986.

Fry, Geoffrey, "The development of the Thatcher government's grand strategy for the Civil Service," Public Administration 62:3 (1984), 322-335. https://doi.org/10.1111/j.14679299.1984.tb00566.x

Gane, Nicholas, "The emergence of neoliberalism," Theory, Culture and Society 31:4 (2014), 327. https://doi.org/10.1177/0263276413506944

Gordon, Colin, "Governmentality and the genealogy of politics," Education and Research 39:4 (2013), 1049-1065. https://doi.org/10.1590/S1517-97022013000400015

Gowan, Peter, "The origins of the administrative elite," New Left Review 162 (March/April 1987), 4-34.

Green, Ewen H. H., Ideologies of Conservatism. Oxford: Oxford University Press, 2002.

Guy, John, "The rhetoric of counsel in early modern England," in Tudor Political Culture, ed. Dale Hoak, 292-310. Cambridge, Cambridge University Press, 1995.

Haldane, Richard, “An organized Civil Service," Public Administration 1:1 (1923), 6-16. https://doi.org/10.1111/j.1467-9299.1923.tb02131.x

Jenkins, Kate, Karen Caines, and Andrew Jackson, Improving Management in Government: The Next Steps. London: Stationery Office, 1988.

Joyce, Patrick, The State of Freedom. Cambridge: Cambridge University Press, 2013.

Jowett, Benjamin, “Introduction” [1871], in Plato, Charmides, 3-28. London: Good Press, 2019.

Lowe, Rodney, The Official History of the British Civil Service. London: Routledge, 2011.

Machiavelli, Niccolò, The Prince [1513]. London: Wordsworth Editions, 1993.

Marquand, David, The Decline of the Public: The Hollowing Out of Citizenship. Cambridge: Polity.

Maude, Francis, Speech at Civil Service World Conference. November, 2009a.

Maude, Francis, Conference Speech. Manchester, October, 2009b.

More, Thomas, Utopia [1515]. London: Penguin, 2012.

Niskanen, William, Bureaucracy: Servant or Master. London: IEA, 1971. 
O'Malley, Pat, Lorna Weir, and Clifford Shearing, "Governmentality, criticism, politics," Economy and Society 26:4 (1997), 501-527. https://doi.org/10.1080/03085149700000026

Osborne, Thomas, "Bureaucracy as a vocation", Journal of Historical Sociology 7:3 (1994), 289313. https://doi.org/10.1111/j.1467-6443.1994.tb00067.x

O'Toole, Barry, The Ideal of Public Service. Routledge, London, 2006.

Parliamentary Papers (PP), Report on the Organization of the Permanent Civil Service IX. London: Eyre and Spottiswoode, 1854. https://www.civilservant.org.uk/library/1854_Northcote_Trevelyan_Report.pdf.

Paul, Joanne, "Serving the public by advising the ruler," in The European Public Servant, eds. Fritz Sagar and Patrick Overeem, 37-52. Colchester: ECPR Press, 2015.

Paul, Joanne, Counsel and Command in early Modern English Thought. Cambridge: Cambridge University Press, 2020

Perkin, Harold, The Origins of Modern English Society [1969]. London: Routledge, 2002.

Pilkington, Colin, The Civil Service in Britain Today. Manchester: Manchester University Press, 1999.

Plowden, William, "What Prospects for the Civil Service?," Journal of the Royal Society of Arts 133:5348 (1985), 526-543. https://www.jstor.org/stable/41373997.

Ponting, Clive, The Right to Know. London: Sphere, 1985.

Ponting, Clive, Whitehall Tragedy and Farce. London: Sphere, 1986.

Prime Minister, The Civil Service Continuity and Change, CM 2627. London: Stationery Office, 1994. https://www.civilservant.org.uk/library/1994_continuity_and_change.pdf.

Rapp, Claudia, Holy Bishops in Late Antiquity: The Nature of Christian Leadership in the Age of Transition. Berkeley: University of California, 2013.

Rhodes, Roderick L., John Wanna, and Patrcik Weller, Comparing Westminster. Oxford: Oxford University Press, 2009.

Rose, Nikolas, Powers of Freedom. Cambridge: Cambridge University Press, 1999.

Rose, Jacqueline, "The problem of political counsel," in The Politics of Counsel in England and Wales 1286-1707, ed. Jacqueline Rose, 1-43. Oxford: Oxford University Press, 2016.

Skinner, Quentin, The Foundations of Modern Political Thought Volume One. Cambridge: Cambridge University Press, 1978.

Stanley, Arthur P., Stanley's Life of Arnold [1840]. London: John Murray, 1895.

Stopper, M.R., “Greek philosophy and the Victorians," Phronesis $26: 3$ (1981), 267-285. https://doi.org/10.1163/156852881X00042.

Thatcher, Margaret, The Downing Street Years. London: Harper Collins, 1993.

Tomlin, Lord, Royal Commission on the Civil Service 1929-1931, CMD. 3909. London: Stationery Office, 1931.

Triantafillou, Peter, Neoliberal Power and Public Management Reforms. Manchester: Manchester University Press, 2017.

Turner, Frank M., The Greek Heritage in Victorian Britain. New Haven: Yale University Press, 1980. 
Van Renswoude, Irene, The Rhetoric of Free Speech in Late Antiquity and the Early Middle Ages. Cambridge: Cambridge University Press, 2019.

Vance, Norman, The Sinews of the Spirit: the ideal of Christian manliness in Victorian literature and religious thought. Cambridge: Cambridge University Press, 1985.

Vincent, David, The Culture of Secrecy. Oxford: Oxford University Press, 1998.

Wass, Douglas, Government and Governed. London: Routledge, 1983b.

Wass, Douglas, “The public service in modern society," Public Administration 61:1 (1983b), 720.

Winn, William, “Tom Brown's schooldays and the development of 'muscular Christianity," Church History 29:11 (1960), 64-73. https://doi.org/10.2307/3161617.

Young, Hugo, and Anne Sloman, No Minister. London: BBC, 1982.

Author info

Edward Barratt

ebarratt@essex.ac

Senior Lecturer in Organisation Studies and Human Resource Management

Essex Business School

Essex University

United Kingdom

Edward Barratt has written extensively about the later work of Michel Foucault in the field of organization and management studies. His current research interests concern the histories of management and ethical codification in the British Civil Service and the history of the concept of stake-holding, especially in the early years of 'New Labour' in Britain. 